\title{
Government Agency Product Endorsements and Stock Valuations: A COVID-19 Event Study
}

\author{
Mark Schaub ${ }^{1}$ \\ ${ }^{1}$ Professor of Finance, Department of Economics and Finance, Stephen F. Austin State University, USA \\ Correspondence: Mark Schaub, Professor of Finance, Department of Economics and Finance, P.O. Box 13009, \\ SFA Station, Stephen F. Austin State University, Nacogdoches, TX 75962-3009, USA. Tel: 936-468-1505. \\ E-mail: schaubm@sfasu.edu; ORCID: 0000-0002-6911-9347
}

Received: February 20, 2021

Accepted: March 18, 2021

Online Published: April 10, 2021

doi:10.5539/ijef.v13n5p1

URL: https://doi.org/10.5539/ijef.v13n5p1

\begin{abstract}
During the COVID-19 pandemic, a US government agency (the Environmental Protection Agency) made two announcements recommending the products of 2 different firms in the Household \& Personal Products industry. The announcements were official and posted to the EPA's website on the dates of March 3, 2020 and July 6, 2020. Evidence shows these announcements added value to the firms that were promoted. Also, on a risk-adjusted and head-to-head basis, these announcing firms significantly outperformed the other large firms in the industry around the date of the announcements.
\end{abstract}

Keywords: COVID-19, asset selection, early wealth effects, event studies

\section{Introduction}

In 2020, the Environmental Protection Agency (henceforth EPA) made two official announcements plugging products in the Household \& Personal Products industry. The first announcement on March 3, 2020 encouraged the use of specific Lysol and Clorox products for cleaning (see EPA's Registered Antimicrobial Products for Use Against Novel Coronavirus SARS-CoV-2, the Cause of COVID-19). A second news release by the EPA declared that certain Lysol products were officially tested and approved for surface cleaning (see News Release from Headquarters: EPA approves first surface disinfectant products tested on the SARS-CoV-2 virus). Historical and fundamental betas suggest companies in this industry tend to have very low systematic risk. This study looks to determine what wealth revaluations accompanied the EPA announcements for the firms promoted versus that of the major industry rival firms and an important market index.

The paper investigates the reaction for plugged firms and industry rivals around the date of the EPA pronouncements. Fortunately the second announcement was not made during potential conflicting events (in March 2020 the stock market had great volatility before rebounding). Further sections include a background of sample event studies, a methods section, results and conclusions.

\section{Background}

Event studies are popular in the financial literature. Most look at how an announcement or release of news impacts asset valuations in a test of market efficiency. In an efficient market, prices react immediately and accurately to new information. However, sometimes the uncoordinated reaction by participants results in overreaction where large decreases in valuations are followed by a series of increases or large increases in valuations are followed by profit taking the next few days. Table 1 gives a brief presentation of some of the better known and a few of the lesser known event studies that illustrate how information releases and announcements significantly impact asset values. This list barely scratches the surface of all of the event studies, therefore it should not be considered more than just a guide for where this type of study leads researchers (it includes mostly older but a broad variety of investigations).

The studies in Table 1 show that company level, industry level and even country-level announcements impact equity values immediately. Of special interest to this paper is the Schaub (2008) study of how the Martha Stewart sentencing resulted, not only in a large overreaction in that firm's price (a 37 percent increase the day of the announcement followed by a few days of decline), but also what the author calls the reverse-competitive effect. Normally a competitive effect occurs when bad news for one firm is good news for rivals (as indicated by 
significant stock value increases for firms in the same industry). The reverse competitive effect resulted when the good news for the announcing firm simultaneously resulted in significant equity declines for the industry rivals.

Table 1. Broad event study literature review

\begin{tabular}{ll}
\hline Harkavy (1953) & Equity valuations respond to dividend announcements \\
Ball and Brown (1968) & Equity valuations respond to earnings announcements \\
Fama et al. (1969) & Stock splits signal new information about a company's future earnings \\
Litzenberger and Ramaswamy (1982) & Tax treatment of dividends affects equity values \\
Jensen and Ruback (1983) & Corporate takeover announcements affects stock prices \\
Johnson et al. (1985) & CEO deaths affect share valuations \\
DeBondt and Thaler (1985, 1987) & Investors initially overreact (oversell) to negative news about firms \\
Ohlson (1995), Athari (2013) & Dividend and earning announcements affect stock prices \\
Loughran and Ritter (1995) & Investors respond negatively to new stock issues (seasoned equity issues, not IPOs) \\
Spiess and Affleck-Graves (1995) & SEOs not only receive negative initial return reactions, they also underperform in the long run \\
Ikenberry et al. (1995) & Equity values increase upon announcements of equity repurchases \\
Jones (1996) & Equity values immediately decline following a media announcement of a Going Concern audit \\
& opinion \\
Bhagat et al. (1998) & Equity valuations decrease upon the announcement of impending lawsuits \\
Schaub (2008) & Martha Stewarts' company gained over 30\% when she received a light sentence and rival firms \\
& lost value \\
Schaub (2010) & Debt buyback announcements cause stock values of announcing firm to go up \\
Schaub (2017a, 2019a, 2020) & The 2016 US Presidential election results negatively impacted ADRs from Mexico short-term \\
Schaub (2017b, 2019b, 2020) & and long-term but the vote may not have impacted REITs \\
& UK ADRs lost short-term value and the Great Britain Pound lost value short-term and long-term \\
\end{tabular}

Additional event studies dealing with industries, macro-level impacts on stock markets or asset pricing may be examined. Fu and Qjan (2014) and Kirikkaleli et al. (2018) examine events in the real estate industry. Schaub (2021) examines how an announcement by the OCC allowing for the use of stablecoins by US banks impacted cryptocurrency valuations. Schaub and Phares (2020) note unexpected Presidential election results did not substantially impact cryptocurrencies. Some overreaction studies include Kashif et al. (2018) finding evidence of overreaction on the Karachi Stock Exchange. Also, Rehman and Said (2019) examine overreaction in Pakistan and Schaub, Lee and Chun (2008) find overreaction in Korea, Hong Kong and Japan. Finally, Thomas and Zhang (2008) and Schaub (2006) find overreaction dealing with firms announcing going concern audit opinions and intra-industry impacts of some firms releasing earnings before others in the industry.

\section{Sample and Methods}

This study investigates the impact of announcements by the Environmental Protection Agency that plugged products of specific firms in the Household \& Personal Products industry. Two announcements were made on the EPA website: 1) on March 3, 2020 the EPA listed Lysol and Clorox products as being EPA registered antimicrobial products for use against the Novel Coronavirus that causes COVID-19, and 2) on July 6, 2020 the EPA offered a "news release from headquarters" that stated specific Lysol products were tested and approved as surface disinfectants to combat COVID-19. The second announcement was followed up with a story by Yahoo! News on July 8.

To test significance related to the announcements, the equity valuations of the firms that produce Clorox and Lysol Products (Clorox and Reckitt Benckiser respectively) are compared head-to-head with the S\&P 500 index, the rival firms in the industry and using risk-adjusted returns of the announcing firms versus industry rivals. The list of industry participants, including rival firms, include the 15 largest Household \& Personal Products firms on the Forbes Global 2000. Table 2 shows these 15 firms. 
Table 2. Sample of household \& personal products firms

\begin{tabular}{lc}
\hline Company Name & Ticker \\
\hline Proctor \& Gamble & PG \\
Unilever & UL \\
L'Oreal & LRLCY \\
Reckitt Benckiser (Lysol) & RBGLY \\
Colgate-Palmolive & CL \\
Clorox Co. & CLX \\
Kimberly-Clark & KMB \\
Henkel & HENKY \\
Estee Lauder. & EL \\
Kao Corp & KAOOY \\
Essity & ETTYF \\
Beiersdorf. & BDRFY \\
Coty & COTY \\
Givaudan & GVDNY \\
Shiseido & SSDOY \\
\hline
\end{tabular}

Note. This sample is obtained from the Forbes Global 2000 rankings and represents the 15 largest global companies in the Household \& Personal Products industry.

Equations 1 and 2 describe the process for computing average market adjusted and average risk-adjusted excess returns for statistical testing. The market-adjusted excess return for each security $i$ on day $t\left(a r_{i t}\right)$ is computed as the difference between the return of the security on day $t\left(r_{i t}\right)$ and the return of the market on day $t\left(r_{m t}\right)$ as shown in equation 1 below. For computing risk-adjusted abnormal returns, $r_{\mathrm{mt}}$ is simply multiplied by the stock's beta. The S\&P 500 index daily returns were used to proxy the market and the companies' 5 -year monthly betas were used to make the risk adjustment in computing risk-adjusted returns. The Household \& Personal Products industry is an historically low systematic risk industry with an industry average beta (for the 15 largest firms) of .51 (in fact, 14 of the 15 firms have betas below 1 and 10 out of 15 have betas below the average of .51).

$$
a r_{i t}=r_{i t}-r_{m t}
$$

Equation 2 computes the average market-adjusted excess returns $\left(\mathrm{MAR}_{\mathrm{t}}\right)$ and the risk-adjusted excess returns for the announcing firm and rival sample for day $t$ as the simple average of the sum of the adjusted returns of each of the $\mathrm{n}$ securities during day $\mathrm{t}$.

$$
M A R_{t}=\frac{1}{n}\left[\sum_{i=1}^{n} a r_{i t}\right]
$$

All rival average returns and announcing firm versus rival return differences were tested to determine significance using a Z-score. The respective p-values for these tests are reported with a p-value of .10 or less indicating the average adjusted return or excess return is significantly different from 0 . To incorporate any effects of leakage or subsequent announcements, besides reporting daily returns starting 5 days before the official announcement date up to 5 days afterwards, returns during the event windows of one day before until one day after (denoted $-1,+1)$ and the event date until 5 days later (denoted $0,+5$ ) also receive attention in the results.

\section{Results}

Tables 3, 4 and 5 summarize the performance starting 5 days before the announcement dates and ending 5 days afterwards for the announcing firms and industry rivals. The first announcement date was March 3, 2020 and promoted Clorox and Reckitt Benckiser. This event window may have had confounding events due to the extreme market volatility during that month related to reactions to COVID, which basically forced shutdowns of certain businesses and significantly impacted "nonessential" industries. The second announcement by the EPA on July 6, 2020 plugged Lysol products (made by Reckitt Benckiser) and was during a less volatile market as many COVID-related affects had already been priced into equities.

Table 3 compares the returns of Clorox to the market index and industry rivals on a head-to-head and risk adjusted basis, while Table 4 does the same for Reckitt Benckiser (maker of Lysol). These two tables cover the first announcement made on March 3, 2020 by the EPA. A glance at the S\&P 500 daily returns show how volatile the market was during the event window of $(-5,+5)$ relative to the announcement date. The Household \& Personal Products industry performed well on a risk-adjusted basis with over 3 percent average abnormal returns 
for both relevant windows of $(-1,+1)$ and $(0,+5)$. Both Clorox and Reckitt Benckiser significantly outperformed the industry for the $(-1,+1)$ window while the results for the $(0,+5)$ window were mixed but significant.

Table 3. Clorox and industry rival returns and cumulative returns from 03/03/20 announcement

\begin{tabular}{ccccc}
\hline Panel A. Clorox returns & \multicolumn{5}{c}{} \\
\hline Day & Clorox Daily Return & S\&P 500 Daily Return & Clorox Excess Return & Clorox Abnormal Return \\
\hline-5 & $0.39 \%$ & $-3.03 \%$ & $3.42 \%$ & $1.15 \%$ \\
-4 & $0.11 \%$ & $-0.38 \%$ & $0.49 \%$ & $0.20 \%$ \\
-3 & $0.40 \%$ & $-4.42 \%$ & $4.82 \%$ & $1.50 \%$ \\
-2 & $-5.50 \%$ & $-0.82 \%$ & $-4.68 \%$ & $-5.29 \%$ \\
-1 & $7.90 \%$ & $4.60 \%$ & $3.29 \%$ & $6.75 \%$ \\
$\mathbf{0}$ & $\mathbf{- 2 . 4 1 \%}$ & $\mathbf{- 2 . 8 1 \%}$ & $\mathbf{0 . 4 0 \%}$ & $\mathbf{- 1 . 7 0 \%}$ \\
+1 & $2.77 \%$ & $4.22 \%$ & $-1.45 \%$ & $1.71 \%$ \\
+2 & $1.93 \%$ & $-3.39 \%$ & $5.32 \%$ & $2.78 \%$ \\
+3 & $-1.47 \%$ & $-1.71 \%$ & $0.23 \%$ & $-1.05 \%$ \\
+4 & $0.95 \%$ & $-7.60 \%$ & $8.54 \%$ & $2.85 \%$ \\
+5 & $0.06 \%$ & $4.94 \%$ & $-4.88 \%$ & $-1.18 \%$ \\
$(-\mathbf{1},+1)$ & $\mathbf{8 . 2 6 \%}$ & $\mathbf{6 . 0 1 \%}$ & $\mathbf{2 . 2 5 \%}$ & $\mathbf{6 . 7 6 \%}$ \\
$(\mathbf{0},+5)$ & $\mathbf{1 . 8 2 \%}$ & $\mathbf{- 6 . 3 5 \%}$ & $\mathbf{8 . 1 7 \%}$ & $\mathbf{3 . 4 1 \%}$ \\
\hline
\end{tabular}

\begin{tabular}{|c|c|c|c|c|c|c|}
\hline Day & $\begin{array}{c}\text { Rival Daily Avg } \\
\text { Return }\end{array}$ & P-Value & $\begin{array}{c}\text { Rival Daily Average } \\
\text { Excess Return }\end{array}$ & P-Value & $\begin{array}{c}\text { Industry Avg. } \\
\text { Abnormal Return }\end{array}$ & P-Value \\
\hline-5 & $-1.36 \%$ & 0.00 & $1.67 \%$ & 0.00 & $0.31 \%$ & 0.27 \\
\hline-4 & $-0.67 \%$ & 0.03 & $-0.30 \%$ & 0.21 & $-0.47 \%$ & 0.07 \\
\hline-3 & $-2.69 \%$ & 0.00 & $1.72 \%$ & 0.00 & $-0.25 \%$ & 0.35 \\
\hline-2 & $-1.08 \%$ & 0.01 & $-0.26 \%$ & 0.29 & $-0.62 \%$ & 0.07 \\
\hline-1 & $3.03 \%$ & 0.00 & $-1.57 \%$ & 0.04 & $0.49 \%$ & 0.34 \\
\hline 0 & $-0.05 \%$ & 0.47 & $2.76 \%$ & 0.00 & $1.50 \%$ & 0.00 \\
\hline+1 & $3.58 \%$ & 0.00 & $-0.64 \%$ & 0.09 & $1.24 \%$ & 0.05 \\
\hline+2 & $-2.11 \%$ & 0.00 & $1.28 \%$ & 0.02 & $-0.24 \%$ & 0.36 \\
\hline+3 & $0.39 \%$ & 0.21 & $2.09 \%$ & 0.00 & $1.33 \%$ & 0.00 \\
\hline+4 & $-4.42 \%$ & 0.00 & $3.18 \%$ & 0.00 & $-0.23 \%$ & 0.39 \\
\hline+5 & $2.18 \%$ & 0.00 & $-2.76 \%$ & 0.00 & $-0.55 \%$ & 0.21 \\
\hline$(-1,+1)$ & $6.55 \%$ & 0.00 & $0.54 \%$ & 0.36 & $3.23 \%$ & 0.01 \\
\hline$(0,+5)$ & $-0.45 \%$ & 0.42 & $5.90 \%$ & 0.00 & $3.06 \%$ & 0.03 \\
\hline
\end{tabular}

Panel C. Announcing Firm and Industry rival excess returns (13 rivals excluding Reckitt Benckiser)

\begin{tabular}{lcccc}
\hline Window & $\begin{array}{c}\text { Excess Window Returns (Announcing } \\
\text { Minus Rival Average) }\end{array}$ & P-Value & $\begin{array}{c}\text { Excess Window Average Abnormal } \\
\text { Returns (Announcing Versus Industry) }\end{array}$ & P-Value \\
\hline$(-1,+1)$ & $+1.71 \%$ & $\mathbf{0 . 0 0}$ & $+3.53 \%$ & $\mathbf{0 . 0 0}$ \\
$(0,+5)$ & $+2.27 \%$ & $\mathbf{0 . 0 0}$ & $+0.35 \%$ & $\mathbf{0 . 0 0}$ \\
\hline
\end{tabular}

Note. Panel A reports the daily returns for the announcing firm, the corresponding daily returns of the market index proxied by the S\&P 500, the amount by which the announcing firm's returns exceeded that of the market and the risk-adjusted abnormal daily return of the announcing firm versus the market. Returns for the windows of $(-1,+1)$ and $(0,+5)$ trading days relative to the announcing date of 03/03/20 are also reported. Panel B reports the event study results for 13 rival firms also in the Household \& Personal Products industry and excludes the co-announcing firm of Reckitt Benckiser. P-values in bold italics indicate significance at the .10 alpha level. Panel C presents the cumulative excess returns and abnormal returns comparing the announcing firm to the 13 industry rivals around the event windows ( -1 , $+1)$, and $(0,+5)$ trading days relative to the announcement date. 
Table 4. Lysol and industry rival returns and cumulative returns from 03/03/20 announcement

\begin{tabular}{ccccc}
\hline \multicolumn{5}{c}{ Panel A. Reckitt Benckiser (maker of Lysol) returns } \\
\hline Day & Lysol Daily Return & S\&P 500 Daily Return & Lysol Excess Return & Lysol Abnormal Return \\
\hline-5 & $-2.93 \%$ & $-3.03 \%$ & $0.09 \%$ & $-2.18 \%$ \\
-4 & $-0.06 \%$ & $-0.38 \%$ & $0.31 \%$ & $0.03 \%$ \\
-3 & $-4.10 \%$ & $-4.42 \%$ & $0.32 \%$ & $-2.99 \%$ \\
-2 & $-1.77 \%$ & $-0.82 \%$ & $-0.95 \%$ & $-1.57 \%$ \\
-1 & $0.67 \%$ & $4.60 \%$ & $-3.94 \%$ & $-0.48 \%$ \\
$\mathbf{0}$ & $\mathbf{- 0 . 3 3 \%}$ & $\mathbf{- 2 . 8 1 \%}$ & $\mathbf{2 . 4 8 \%} \%$ \\
+1 & $7.00 \%$ & $4.22 \%$ & $2.78 \%$ & $\mathbf{0 . 3 7 \%}$ \\
+2 & $0.12 \%$ & $-3.39 \%$ & $3.52 \%$ & $0.97 \%$ \\
+3 & $-0.62 \%$ & $-1.71 \%$ & $1.08 \%$ & $-0.20 \%$ \\
+4 & $-5.76 \%$ & $-7.60 \%$ & $1.84 \%$ & $-3.86 \%$ \\
+5 & $0.47 \%$ & $4.94 \%$ & $-4.47 \%$ & $-0.77 \%$ \\
$(-\mathbf{1}+\mathbf{1})$ & $\mathbf{7 . 3 4 \%}$ & $\mathbf{6 . 0 1 \%}$ & $\mathbf{1 . 3 2 \%}$ & $\mathbf{5 . 8 3 \%}$ \\
$(\mathbf{0 , + 5 )}$ & $\mathbf{0 . 8 7 \%}$ & $\mathbf{- 6 . 3 5 \%}$ & $\mathbf{7 . 2 2 \%}$ & $\mathbf{2 . 4 6 \%}$ \\
\hline
\end{tabular}

\begin{tabular}{|c|c|c|c|c|c|c|}
\hline \multicolumn{7}{|c|}{ Panel B. Industry rival abnormal returns (13 rivals excluding Clorox) } \\
\hline Day & Rival Daily Avg Return & P-Value & $\begin{array}{c}\text { Rival Daily Average Excess } \\
\text { Return } \\
\end{array}$ & P-Value & $\begin{array}{c}\text { Industry Avg. Abnormal } \\
\text { Return } \\
\end{array}$ & P-Value \\
\hline-5 & $-1.36 \%$ & 0.00 & $1.67 \%$ & 0.00 & $0.31 \%$ & 0.27 \\
\hline-4 & $-0.67 \%$ & 0.03 & $-0.30 \%$ & 0.21 & $-0.47 \%$ & 0.07 \\
\hline-3 & $-2.69 \%$ & 0.00 & $1.72 \%$ & 0.00 & $-0.25 \%$ & 0.35 \\
\hline-2 & $-1.08 \%$ & 0.01 & $-0.26 \%$ & 0.29 & $-0.62 \%$ & 0.07 \\
\hline-1 & $3.03 \%$ & 0.00 & $-1.57 \%$ & 0.04 & $0.49 \%$ & 0.34 \\
\hline 0 & $-0.05 \%$ & 0.47 & $2.76 \%$ & 0.00 & $1.50 \%$ & 0.00 \\
\hline+1 & $3.58 \%$ & 0.00 & $-0.64 \%$ & 0.09 & $1.24 \%$ & 0.05 \\
\hline+2 & $-2.11 \%$ & 0.00 & $1.28 \%$ & 0.02 & $-0.24 \%$ & 0.36 \\
\hline+3 & $0.39 \%$ & 0.21 & $2.09 \%$ & 0.00 & $1.33 \%$ & 0.00 \\
\hline+4 & $-4.42 \%$ & 0.00 & $3.18 \%$ & 0.00 & $-0.23 \%$ & 0.39 \\
\hline+5 & $2.18 \%$ & 0.00 & $-2.76 \%$ & 0.00 & $-0.55 \%$ & 0.21 \\
\hline$(-1,+1)$ & $6.55 \%$ & 0.00 & $0.54 \%$ & 0.36 & $3.23 \%$ & 0.01 \\
\hline$(0,+5)$ & $-0.45 \%$ & 0.42 & $5.90 \%$ & 0.00 & $3.06 \%$ & 0.03 \\
\hline
\end{tabular}

\begin{tabular}{ccccc}
\hline Panel C. Announcing Firm and Industry rival excess returns (13 rivals excluding Clorox) \\
\hline $\begin{array}{c}\text { Window } \\
\text { Excess Window Returns (Announcing } \\
\text { Minus Rival Average) }\end{array}$ & P-Value & $\begin{array}{c}\text { Excess Window Average Abnormal } \\
\text { Returns (Announcing Versus Industry) }\end{array}$ & P-Value \\
\hline$(-1,+1)$ & $+0.79 \%$ & $\mathbf{0 . 0 0}$ & $+2.60 \%$ & $\mathbf{0 . 0 0}$ \\
$(0,+5)$ & $+1.32 \%$ & $\mathbf{0 . 0 0}$ & $-0.60 \%$ & $\mathbf{0 . 0 0}$ \\
\hline
\end{tabular}

Note. Panel A reports the daily returns for the announcing firm, the corresponding daily returns of the market index proxied by the S\&P 500, the amount by which the announcing firm's returns exceeded that of the market and the risk-adjusted abnormal daily return of the announcing firm versus the market. Returns for the windows of $(-1,+1)$ and $(0,+5)$ trading days relative to the announcing date of $03 / 03 / 20$ are also reported. Panel B reports the event study results for 13 rival firms also in the Household \& Personal Products industry and excludes the co-announcing firm of Clorox. P-values in bold italics indicate significance at the .10 alpha level. Panel $\mathrm{C}$ presents the cumulative excess returns and abnormal returns comparing the announcing firm to the 13 industry rivals for the event windows $(-1,+1)$, and $(0,+5)$ trading days relative to the announcement date.

The second EPA announcement that specifically recommended Lysol spray products on July 6, 2020 saw a nearly 2 percent increase in value for Reckitt Benckiser on the announcement date as well as another nearly 2 percent increase in value when Yahoo! News did a story two days later calling further attention to the EPA announcement as shown in Table 5. The S\&P 500 returns show the July market had settled down versus the March announcement window, giving a better indication of the pure announcement effects. As a result, Lysol (Reckitt Benckiser) had very significant positive returns versus the industry for the $(-1,+1)$ and $(0,+5)$ windows when comparing daily returns and daily abnormal returns. Further, the significant loss of 1 percent in average rival abnormal returns for the window $(0,+5)$ coupled with the significant excess abnormal return of the 
announcing firm of 4.4 percent suggests there may have been a slight reverse competitive effect as outlined in Schaub (2008).

Table 5. Lysol and industry rival returns and cumulative returns from 07/06/20 announcement

\begin{tabular}{ccccc}
\hline \multicolumn{7}{c}{ Panel A. Reckitt Benckiser (maker of Lysol) returns } & \multicolumn{3}{l}{} \\
\hline Day & Lysol Daily Return & S\&P 500 Daily Return & Lysol Excess Return & Lysol Abnormal Return \\
\hline-5 & $0.22 \%$ & $-2.42 \%$ & $2.65 \%$ & $0.83 \%$ \\
-4 & $1.67 \%$ & $1.47 \%$ & $0.20 \%$ & $1.30 \%$ \\
-3 & $1.26 \%$ & $1.54 \%$ & $-0.28 \%$ & $0.87 \%$ \\
-2 & $0.49 \%$ & $0.50 \%$ & $-0.02 \%$ & $0.36 \%$ \\
-1 & $1.40 \%$ & $0.45 \%$ & $0.94 \%$ & $1.29 \%$ \\
0 & $1.86 \%$ & $1.59 \%$ & $0.27 \%$ & $1.46 \%$ \\
+1 & $-0.68 \%$ & $-1.08 \%$ & $0.40 \%$ & $-0.41 \%$ \\
+2 & $1.99 \%$ & $0.78 \%$ & $1.21 \%$ & $1.80 \%$ \\
+3 & $0.10 \%$ & $-0.56 \%$ & $0.67 \%$ & $0.24 \%$ \\
+4 & $1.13 \%$ & $1.05 \%$ & $0.08 \%$ & $0.87 \%$ \\
+5 & $-0.86 \%$ & $-0.94 \%$ & $0.07 \%$ & $-0.63 \%$ \\
$(-\mathbf{1},+1)$ & $\mathbf{2 . 5 8 \%}$ & $\mathbf{0 . 9 6 \%}$ & $\mathbf{1 . 6 2 \%}$ & $\mathbf{2 . 3 4 \%}$ \\
$(\mathbf{0}+\mathbf{+ 5}$ & $\mathbf{3 . 5 4 \%}$ & $\mathbf{0 . 8 4 \%}$ & $\mathbf{2 . 7 1 \%}$ & $\mathbf{3 . 3 3 \%}$ \\
\hline
\end{tabular}

\begin{tabular}{|c|c|c|c|c|c|c|}
\hline \multicolumn{7}{|c|}{ Panel B. Industry rival abnormal returns (14 rivals) } \\
\hline Day & $\begin{array}{c}\text { Rival Daily Avg } \\
\text { Return }\end{array}$ & P-Value & $\begin{array}{c}\text { Rival Daily Average Excess } \\
\text { Return } \\
\end{array}$ & P-Value & $\begin{array}{c}\text { Industry Avg. Abnormal } \\
\text { Return }\end{array}$ & P-Value \\
\hline-5 & $-0.92 \%$ & 0.02 & $1.51 \%$ & 0.00 & $0.37 \%$ & 0.18 \\
\hline-4 & $1.57 \%$ & 0.05 & $0.11 \%$ & 0.46 & $0.80 \%$ & 0.15 \\
\hline-3 & $0.28 \%$ & 0.31 & $-1.26 \%$ & 0.01 & $-0.54 \%$ & 0.23 \\
\hline-2 & $-0.22 \%$ & 0.22 & $-0.73 \%$ & 0.01 & $-0.49 \%$ & 0.08 \\
\hline-1 & $1.01 \%$ & 0.00 & $0.56 \%$ & 0.01 & $0.77 \%$ & 0.00 \\
\hline 0 & $0.07 \%$ & 0.41 & $-1.52 \%$ & 0.00 & $-0.77 \%$ & 0.02 \\
\hline+1 & $-0.54 \%$ & 0.09 & $0.54 \%$ & 0.10 & $0.03 \%$ & 0.47 \\
\hline+2 & $-0.16 \%$ & 0.25 & $-0.94 \%$ & 0.00 & $-0.57 \%$ & 0.01 \\
\hline+3 & $-0.90 \%$ & 0.01 & $-0.33 \%$ & 0.19 & $-0.60 \%$ & 0.04 \\
\hline+4 & $0.98 \%$ & 0.00 & $-0.06 \%$ & 0.40 & $0.43 \%$ & 0.02 \\
\hline+5 & $-0.09 \%$ & 0.38 & $0.85 \%$ & 0.00 & $0.41 \%$ & 0.13 \\
\hline$(-1,+1)$ & $0.54 \%$ & 0.20 & $-0.42 \%$ & 0.28 & $0.03 \%$ & 0.48 \\
\hline$(0,+5)$ & $-0.63 \%$ & 0.23 & $-1.47 \%$ & 0.06 & $-1.07 \%$ & 0.10 \\
\hline
\end{tabular}

Panel C. Announcing Firm and Industry rival excess returns (14 rivals)

\begin{tabular}{ccccc}
\hline Window & $\begin{array}{c}\text { Excess Window Returns (Announcing } \\
\text { Minus Rival Average) }\end{array}$ & P-Value & $\begin{array}{c}\text { Excess Window Average Abnormal } \\
\text { Returns (Announcing Versus Industry) }\end{array}$ & P-Value \\
\hline$(-1,+1)$ & $+2.04 \%$ & $\mathbf{0 . 0 0}$ & $+2.31 \%$ & $\mathbf{0 . 0 0}$ \\
$(0,+5)$ & $+4.17 \%$ & $\mathbf{0 . 0 0}$ & $+4.40 \%$ & $\mathbf{0 . 0 0}$ \\
\hline
\end{tabular}

Note. Panel A reports the daily returns for the announcing firm, the corresponding daily returns of the market index proxied by the S\&P 500 , the amount by which the announcing firm's returns exceeded that of the market and the risk-adjusted abnormal daily return of the announcing firm versus the market. Returns for the windows of $(-1,+1)$ and $(0,+5)$ trading days relative to the announcing date of $07 / 06 / 20$ are also reported. Panel B reports the event study results for 14 rival firms also in the Household \& Personal Products industry. P-values in bold italics indicate significance at the .10 alpha level. Panel $\mathrm{C}$ presents the cumulative excess returns and abnormal returns comparing the announcing firm to the 14 industry rivals around the windows $(-1,+1)$, and $(0,+5)$ trading days relative to the announcement date.

\section{Conclusions}

This study provides some evidence that announcements by the government agency (EPA) that promoted products for use to combat COVID-19 resulted in significant stock price revaluations for the promoted firms versus top industry rivals. This expands the event study literature into the arena of how announcements by a government 
agency promoting products of specific firms within an industry can significantly impact investor returns. Because of the reactions of governments around the world regarding permissible behaviors of citizens, these announcements may be considered ways to avert personal harm during a global emergency. The study results suggest Clorox and Lysol products brought their firms additional value when their products were recommended and certified as "tested and approved" for combating the COVID-19 virus by the Environmental Protection Agency.

\section{Acknowledgments}

Funding for this article was received from the College of Business at Stephen F. Austin State University in the form of professional development awards for performing research. The author thanks an anonymous referee for revision recommendations and the editorial assistant, Michael Zhang, for personal assistance, including manuscript preparation. All errors are mine.

\section{References}

Athari, S. A. (2013). Market Reaction To Dividend Announcement An Event Study Analysis. 1th International Conference on New Directions in Business, Management, Finance and Economics.

Ball, R. J., \& Brown, P. (1968). An empirical evaluation of accounting income numbers. Journal of Accounting Research, 6, 159-178. https://doi.org/10.2307/2490232

Bhagat, S., Bizjak, J., \& Coles, J. L. (1998). The Shareholder Wealth Implications of Corporate Lawsuits. Financial Management, 27(4), 5-27. https://doi.org/10.2307/3666410

DeBondt, W., \& Thaler, R. (1985). Does the Stock Market Overreact? Journal of Finance, 40(3), 793-805. https://doi.org/10.1111/j.1540-6261.1985.tb05004.x

DeBondt, W., \& Thaler, R. (1987). Further Evidence on Investor Overreaction and Stock Market Seasonality. Journal of Finance, 42(2), 557-581. https://doi.org/10.1111/j.1540-6261.1987.tb04569.x

Fama, E., Fisher, L., Jensen, M., \& Roll, R. (1969). The adjustment of stock prices to new information. International Economic Review, 10, 1-21. https://doi.org/10.2307/2525569

Fu, Y., \& Qian, W. (2014). Speculators and Price Overreaction in the Housing Market. Real Estate Economics, 42(4), 977-1007. https://doi.org/10.1111/1540-6229.12071

Harkavy, O. (1953). The Relation between Retained Earnings and Common Stock Prices for Large Listed Corporations. Journal of Finance, 3(1), 283-297. https://doi.org/10.1111/j.1540-6261.1953.tb01170.x

Ikenberry, D., Lakonishok, J., \& Vermaelen, T. (1995). Market underreaction to open market share repurchases. Journal of Financial Economics, 39(1), 181-208. https://doi.org/10.1016/0304-405x(95)00826-Z

Jensen, M., \& Ruback, R. S. (1983). The market for corporate control: The scientific evidence. Journal of Financial Economics, 11, 5-50. https://doi.org/10.1016/0304-405x(83)90004-1

Johnson, W., Bruce, R. M., Nandu, N., \& Herry, N. (1985). An Analysis of the Stock Price Reaction to Sudden Executive Death: Implications for the Management Labor Market. Journal of Accounting and Economics, 7(1), 151-174. https://doi.org/10.1016/0165-4101(85)90034-5

Jones, F. L. (1996). The Information Content of the Auditor's Going Concern Evaluation. Journal of Accounting and Public Policy, 15(1), 1-27. https://doi.org/10.1016/0278-4254(95)00062-3

Kashif, M., Saad, S., Chhapra, I. U., \& Ahmed, F. (2018). An Empirical Evidence of Over Reaction Hypothesis on Karachi Stock Exchange. Asian Economic and Financial Review, 8(4), 449-465. https://doi.org/10.18488/journal.aefr.2018.84.449.465

Kirikkaleli, D., Athari, S. A., \& Ertugrul, H. M. (2018). The real estate industry in Turkey: A time series analysis. The Service Industries Journal, 1, 13. https://doi.org/10.1080/02642069.2018.1444033

Litzenberger, R. H., \& Ramaswamy, K. (1982). The Effects of Dividends on Common Stock Prices: Tax Effects $\begin{array}{lllll}\text { of Information } \quad \text { Effects. Journal of } & \text { Finance, }\end{array}$ https://doi.org/10.1111/j.1540-6261.1982.tb03565.x

Loughran, T., \& Ritter, J. (1995). The new issues puzzle. Journal of Finance, 50(1), 23-52. https://doi.org/10.1111/j.1540-6261.1995.tb05166.x

Ohlson, J. A. (1995). Earnings, Book Values, andDividends in Equity Valuation. Contemporary Accounting Research, 11(2), 661-687. https://doi.org/10.1111/j.1911-3846.1995.tb00461.x 
Rehman, S. U., \& Said, B. (2019). Analysis of Investor Overreaction Effect and Random Walk: A Case Study of Pakistan Stock Exchange. Sarhad Journal of Management Sciences, 5(1), 1-14. https://doi.org/10.31529/sjms.2018.5.1.1

Schaub, M. (2006). Investor Overreaction to Going Concern Audit Opinions. Applied Financial Economics, 16(16), 1163-1170. https://doi.org/10.1080/09603100500447511

Schaub, M. (2008). A Note on Reverse Competition and the Martha Stewart Sentencing. Applied Economics Letters, 15(15), 1159-1161. https://doi.org/10.1080/13504850601018064

Schaub, M. (2010). Short-Term Wealth Effects From Debt Buyback Announcements. Applied Economics Letters, 17(14), 1351-1354. https://doi.org/10.1080/13504850902967506

Schaub, M. (2017a). Initial Wealth Effects of the Brexit Vote on UK ADRs. Applied Economics Letters, 24(17), 1232-1236. https://doi.org/10.1080/13504851.2016.1270398

Schaub, M. (2017b). A Note on the Early Effects of the US Presidential Vote on Mexican ADR Values. Journal of Asset Management, 18(7), 511-515. https://doi.org/10.1057/s41260-017-0043-x

Schaub, M. (2019a). US Presidential Election Effects on Mexican ADRs: A Two-Year Analysis. Applied Economic Letters, 26(20), 1709-1712. https://doi.org/10.1080/13504851.2019.1593313

Schaub, M. (2019b). The Brexit Effect: The Case of UK ADR Performance One Year Later. Applied Economics Letters, 26(1), 5-9. https://doi.org/10.1080/13504851.2018.1430330

Schaub, M. (2020). A Note on the Early Effects of the Brexit and US Presidential Votes on REITs. International Journal of Economics and Finance, 12(6), 14-17. https://doi.org/10.5539/ijef.v12n6p14

Schaub, M. (2021). On the OCC Announcement Allowing US Banks to Use Stable Coins and the Immediate Impact on Cryptocurrency Valuations. Working paper. https://doi.org/10.13140/RG.2.2.26702.79689/1

Schaub, M., Lee, B. S., \& Chun, S. E. (2008). Overreaction and Seasonality in Asian Stock Indices: Evidence From Korea, Hong Kong and Japan. Research in Finance, 24, 169-195. https://doi.org/10.1016/s0196-3821(07)00207-9

Schaub, M., \& Phares, B. (2020). Cryptocurrency Value Changes in Response to National Elections: Do They Behave Like Money or Commodities? Applied Economics Letters, 27(14), 1135-1140. https://doi.org/10.1080/13504851.2019.1673297

Spiess, D. K., \& Affleck-Graves, J. (1995). Underperformance in long-run stock returns following seasoned $\begin{array}{lllll}\text { equity offerings. Journal of Financial } & \text { Economics, } & 38(2), & \text { 243-268. }\end{array}$ https://doi.org/10.1016/0304-405x(94)00817-k

Thomas, J., \& Zhang, F. (2008). Overreaction to Intra-industry Transfers? Journal of Accounting Research, 46(4), 909-940. https://doi.org/10.1111/j.1475-679x.2008.00294.x

\section{Copyrights}

Copyright for this article is retained by the author(s), with first publication rights granted to the journal.

This is an open-access article distributed under the terms and conditions of the Creative Commons Attribution license (http://creativecommons.org/licenses/by/4.0/). 